\title{
Immune cells in the corpus luteum: friends or foes?
}

\author{
Joy L. Pate ${ }^{1}$ and P. Landis Keyes ${ }^{2}$ \\ ${ }^{1}$ Department of Animal Sciences, Ohio State University, OARDC, Wooster, OH 44691, USA; \\ and ${ }^{2}$ Department of Physiology, University of Michigan, Ann Arbor, MI 48109, USA
}

\begin{abstract}
The corpus luteum produces progesterone, which is essential for the maintenance of pregnancy. In the absence of a viable embryo, the corpus luteum must regress rapidly to allow for development of new ovulatory follicles. In many species, luteal regression is initiated by uterine release of $\mathrm{PGF}_{2 \alpha}$, which inhibits steroidogenesis and may launch a cascade of events leading to the ultimate demise of the tissue. Immune cells, primarily macrophages and T lymphocytes, are present in the corpus luteum, particularly at the time of luteolysis. The macrophages are important for ingestion of cellular remnants that result from the death of luteal cells. However, it has also been hypothesized that immune cells are involved directly in the destruction of luteal cells, as well as in the loss of steroidogenesis; this hypothesis is reviewed in the first part of this article. An alternative hypothesis is also presented, namely that immune cells serve to abate an inflammatory response generated by dead and dying luteal cells, in effect, preventing a response that would otherwise damage surrounding ovarian tissues. Finally, the changes in immune cells that accompany maternal recognition of pregnancy and rescue of the corpus luteum are discussed briefly. Inhibition of immune cells in the corpus luteum during early pregnancy may be due to embryonic or uterine signals, or to maintenance of high progesterone concentrations within the luteal tissue.
\end{abstract}

The primary hormonal regulators of the corpus luteum have been studied in depth. Progesterone synthesis is driven by luteotrophic hormones, most commonly $\mathrm{LH}$, although in some species prolactin, FSH or even oestradiol serve as luteotrophic hormones. Much has been learned about the intracellular signal transduction cascades activated by the luteotrophic hormones and the mechanisms involved in regulation of steroidogenic capacity. The corpus luteum is a transitory endocrine gland; thus, in the absence of the appropriate embryonic signal, luteolysis will ensue. In most species other than primates, luteal regression is initiated by the release of $\mathrm{PGF}_{2 \alpha}$ from the uterus, which causes a cascade of events within the corpus luteum that ultimately leads to demise of the tissue (Fig. 1). The primary functional effect of $\mathrm{PGF}_{2 \alpha}$ is to inhibit steroidogenesis stimulated by $\mathrm{LH}$ and both high density (HDL) and low density lipoprotein $(\mathrm{LDL})$. The action of $\mathrm{PGF}_{2 \alpha}$ on luteal cells is transduced via the phospholipase $\mathrm{C}(\mathrm{PLC})$, protein kinase $\mathrm{C}$ (PKC) pathway, and the immediate effect of $\mathrm{PGF}_{2 \alpha}$ is to prevent transport of cholesterol through the mitochondrial membrane. This effect probably occurs as a result of inhibition of synthesis or activity of the steroidogenic acute regulatory protein (StAR), and perhaps other proteins that are important for cholesterol transport. Prostaglandin synthase is stimulated by $\mathrm{PGF}_{2 \alpha}$, allowing for increased synthesis of luteal prostaglandins. Endothelial cells release endothelin 1 in

Email: pate.1@osu.edu response to $\mathrm{PGF}_{2 \alpha}$ which inhibits steroidogenesis by unknown mechanisms. Receptors for $\mathrm{PGF}_{2 \alpha}$ have been identified on large steroidogenic luteal cells. If there are no prostaglandin receptors on small luteal cells, there must be an as yet unidentified factor that communicates the luteolytic signal from large to small steroidogenic cells. After the initial decrease in progesterone, more chronic effects of $\mathrm{PGF}_{2 \alpha}$ include loss of gonadotrophin receptors and disruption of the cytoskeleton; the latter may prevent movement of steroidogenic carrier protein 2-coupled cholesterol through the cytoplasm, or secretion of progesterone. An additional chronic effect of $\mathrm{PGF}_{2 \alpha^{\prime}}$ in association with endothelin 1 , is to cause vasoconstriction of luteal capillaries and apoptosis of capillary endothelial cells, restricting access of steroidogenic cells to gonadotrophin and oxygen. This effect is followed by morphological changes in steroidogenic cells indicative of apoptosis, and a loss in both size and number of first large and then small steroidogenic luteal cells. The model presented (Fig. 1 ) is a result of the work of numerous investigators, and has been reviewed thoroughly by Niswender et al. (2000). Accompanying the changes depicted is the appearance of immune cells as the corpus luteum regresses. The physiological role of these cells has been the subject of debate, which is addressed in this review.

There may be distinct mechanisms to achieve the loss of progesterone and the structural degeneration of the tissue. This is evidenced by the fact that withdrawal of 


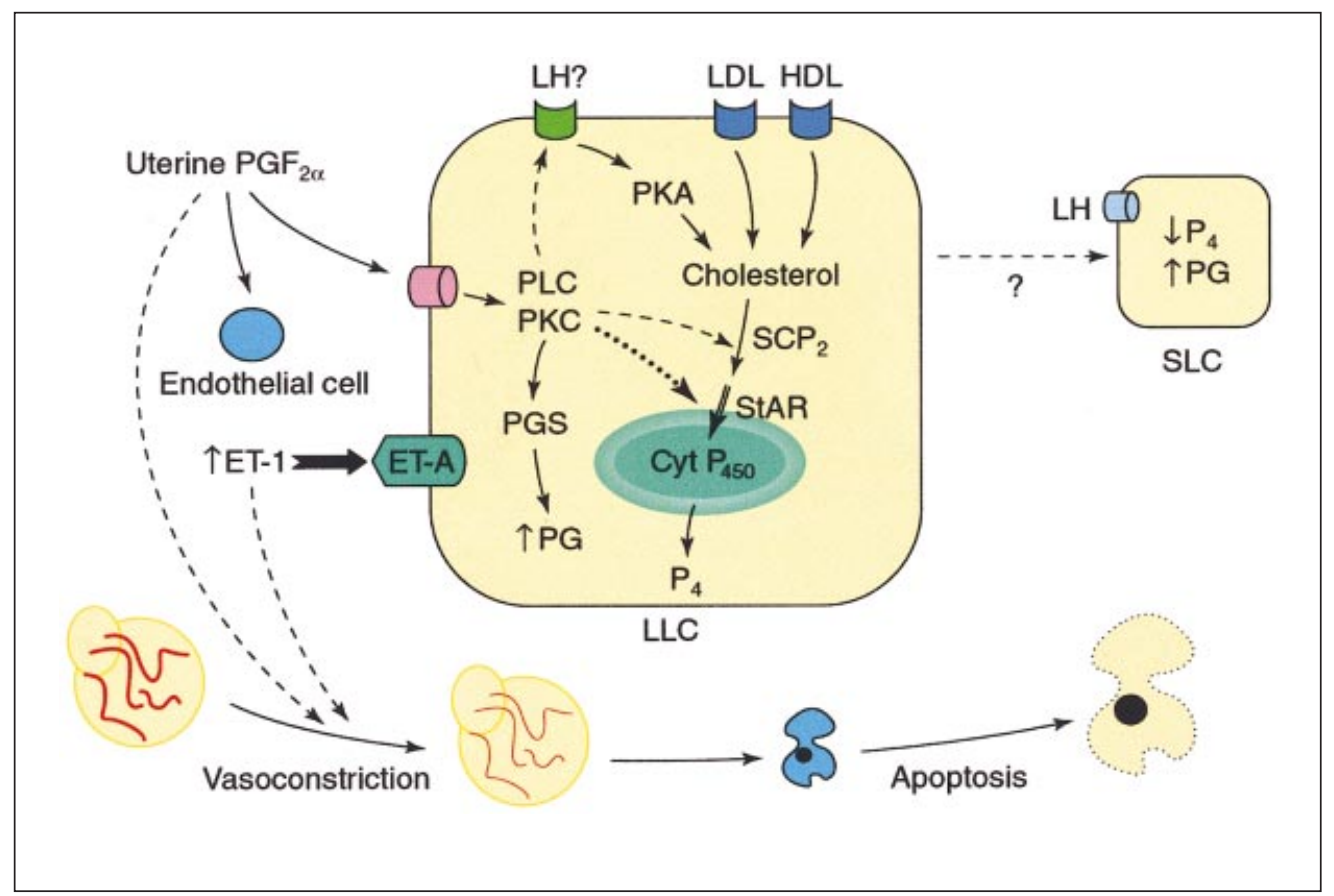

Fig. 1. Prostaglandin (PG)-induced cascade of events that contribute to luteal regression. Intracellular events that occur include activation of phospholipase C (PLC), the protein kinase C (PKC) system, and prostaglandin synthesis via prostaglandin endoperoxide synthase (PGS). Cholesterol translocation to the inner mitochondrial membrane by steroidogenic acute regulatory protein (StAR) is inhibited, resulting in an acute reduction in progesterone synthesis $\left(\mathrm{P}_{4}\right)$. In addition, endothelial cells in the corpus luteum are targets of $\mathrm{PGF}_{2 \alpha}$, releasing endothelin 1 (ET-1) which acts on luteal cells via the ET-A receptor, inhibiting progesterone synthesis. Endothelin 1 and $\mathrm{PGF}_{2 \alpha}$ are also potent vasoconstrictive agents, the actions of which cause a reduction in the luteal blood supply, initiating apoptotic mechanisms that facilitate luteal regression further. Although there is substantial evidence demonstrating communication between small (SLC) and large (LLC) luteal cells, the mechanisms by which luteolytic signals may be conveyed from large to small luteal cells remains unknown. Cyt $\mathrm{P}_{450}$ : cytochrome $\mathrm{P}_{450}$ side-chain cleavage enzyme; HDL: high density lipoprotein; LDL: low density lipoprotein; $\mathrm{SCP}_{2}$ : sterol carrier protein 2.

gonadotrophic support leads to a decrease in progesterone synthesis, yet the corpus luteum retains the capacity for steroidogenesis (Hutchinson and Zeleznik, 1985), and the effects of $\mathrm{PGF}_{2 \alpha}$ in vivo are reversed when cells are placed in vitro (Pate and Nephew, 1988). The decline in progesterone production in vivo is a hallmark of luteolysis, yet it is not sufficient to bring about structural regression of the corpus luteum (Jenkin et al., 1984), and $\mathrm{PGF}_{2 \alpha}$ in vitro can inhibit LH-stimulated steroidogenesis without altering cell viability (Pate and Condon, 1984). Therefore, although $\mathrm{PGF}_{2 \alpha}$ may initiate the loss in steroidogenesis, additional mechanisms must come into play for luteolysis to be completed. These mechanisms, which involve the participation of immune cells, may represent a feature common to luteolysis in all species, including those that are not dependent on uterine prostaglandin to initiate regression.

The role of immune cells in the corpus luteum can be described using two hypotheses. The first hypothesis, which now is supported by considerable evidence, is that immune cells are involved actively in the loss of steroidogenesis and destruction of the tissue. The second hypothesis is that immune cells control a potential inflammatory condition caused by dying cells, and provide a nurturing environment as the cells of the corpus luteum die progressively. Finally, the inhibition of immune cells in the corpus luteum during maternal recognition of pregnancy is discussed briefly. It is not the purpose of this review to provide a comprehensive overview of luteolysis (see Fig. 1 and Niswender et al., 2000). Rather, the intention is to stimulate the reader to think of alternative hypotheses that may explain how immune cells participate in the regression of the corpus luteum.

\section{Immune cells in the corpus luteum}

Lobel and Levy (1968) first described the presence of white blood cells in the bovine corpus luteum. They observed that lymphocytes were present in the connective tissue surrounding the luteal vasculature on day 14 of the oestrous cycle. On days 15-17, the lymphocytes infiltrated among the luteal cells, and by day 19 macrophages were also present. The macrophages were later shown to be involved 
in phagocytosis of cells and cell remnants (Paavola, 1979). Subsequent studies confirmed that lymphocytes and macrophages are present in the corpus luteum throughout the luteal phase (Kirsch et al., 1981; Hume et al., 1984; Bagavandoss et al., 1988). Although there has been one report that there are more macrophages in luteal tissue during the mid-luteal phase (Gaytán et al., 1998a), most investigators have observed an increase in lymphocytes or macrophages in the corpus luteum at the time of luteolysis (Bagavandoss et al., 1988; Best et al., 1996; Takaya et al., 1997; Penny et al., 1999; Bauer et al., 2001). Withdrawal of the luteotrophic hormone oestradiol from the rabbit corpus luteum results in infiltration of macrophages (Naftalin et al., 1997). In rats, macrophage infiltration is associated with the pro-oestrous prolactin surge (Gaytán et al., 1997; Bowen et al., 1999) or a luteolytic injection of prolactin in hypophysectomized rats (Bowen et al., 1996). Recruitment of macrophages into the corpus luteum of rats, rabbits and cows is probably regulated by expression of monocyte chemoattractant protein 1 (MCP-1; Bowen et al., 1996, 1999; Townson et al., 1996; Penny et al., 1998; Penny, 2000). In each of these species there appears to be an increase in expression of MCP-1 at the time of luteolysis, and this is associated with the influx of macrophages. Olson and Townson (2000) have recently reported that intercellular adhesion molecule 1 (ICAM-1) is also expressed during prolactin-induced luteal regression in rats and its expression is associated with the recruitment of monocytes and macrophages into the corpus luteum. Therefore, there are at least two molecules that are increased at the time of luteal regression that may serve to attract, activate and promote adhesion of immune cells in the tissue. Little is known about the molecules involved in recruitment or activation of lymphocytes in luteal tissue. Bauer et al. (2001) reported that most of the T lymphocytes in the corpus luteum migrate into the tissue, but that there is some proliferation of lymphocytes within the tissue. The presence and increase of lymphocytes at the time of luteolysis implies that they may also function in a manner that facilitates regression. It has been hypothesized that immune cells are involved in the onset and progression of luteolysis and have a role beyond that of merely cleaning up cellular debris (Bukovsky and Presl, 1979; Murdoch, 1987; Bagavandoss et al., 1988; Fairchild and Pate, 1989).

\section{Hypothesis I - immune cells as instruments of destruction: direct participation in loss of steroidogenesis and in the demise of luteal cells and tissue}

\section{Hormonal regulation of luteolysis and the role of immune cells in the loss of steroidogenesis}

Non-steroidogenic cells out-number steroidogenic cells in the corpus luteum, and probably participate in the regulation of steroidogenic cell function. Milvae (2000) reviewed the relationships between the endothelial cells and steroidogenic cells, with particular emphasis on the hypothesized role of endothelin 1. Endothelial cells, fibroblasts and immune cells secrete a variety of potential paracrine regulators of ovarian function, such as growth factors, prostaglandins and lipoxygenase products. As macrophages and $T$ lymphocytes become activated within a tissue they secrete cytokines, which potentiate the immune response. Cytokines may exert either positive or negative effects on endocrine cell function. Both the synthesis and action of oestradiol, which is a luteotrophic hormone in pigs, are inhibited by tumour necrosis factor $\alpha$ (TNF- $\alpha$; Wuttke et al., 1997a). In microdialysed pig corpus luteum, $\mathrm{PGF}_{2 \alpha}$ causes an increase in progesterone production. However, when corpora lutea are pretreated with TNF- $\alpha$, $\mathrm{PGF}_{2 \alpha}$ brings about a further reduction in progesterone over that caused by TNF- $\alpha$ alone (Wuttke et al., 1998). These authors speculated that TNF- $\alpha$ serves as a signal within the pig corpus luteum that switches the action of $\mathrm{PGF}_{2 \alpha}$ from luteotrophic to luteolytic. It is plausible that the luteolytic action of $\mathrm{PGF}_{2 \alpha}$ is mediated by local release of a number of cytokines that may cause a further decrease in progesterone production. Cytokines may mediate $\mathrm{PGF}_{2 \alpha}$-induced increases in phospholipase $A_{2}$, formation of reactive oxygen species and apoptosis, all which occur during luteolysis (Wu and Carlson, 1990; Behrman et al., 1991; Juengel et al., 1993). There may even be a positive feedback between production of cytokines and further release of $\mathrm{PGF}_{2 \alpha}$, as TNF- $\alpha$ can stimulate PGF $_{2 \alpha}$ release from endometrial slices late in the oestrous cycle to a greater extent than can oxytocin (Miyamoto et al., 2000).

TNF- $\alpha$ has been detected in rabbit (Bagavandoss et al., 1990), bovine (Roby and Terranova, 1989), ovine (Ji et al., 1991) and pig (Zhao et al., 1998) corpora lutea, localized primarily to the resident macrophages. However, there are reports that TNF- $\alpha$ is also found in large luteal cells or granulosal cells (Roby and Terranova, 1989; Roby et al., 1990; Zolti et al., 1990; Kondo et al., 1995; Wuttke et al., 1997b). The mRNA for TNF- $\alpha$ is present in the bovine corpus luteum throughout its lifespan (Petroff et al., 1999), but secreted TNF- $\alpha$ protein or bioactivity could be detected only after the initial decrease in plasma progesterone in bovine and ovine corpora lutea (Ji et al., 1991; Shaw and Britt, 1995). These data are consistent with a role for TNF- $\alpha$ in facilitating luteolysis after PGF $_{2 \alpha}$ causes the initial decline in progesterone.

Acute exposure to TNF- $\alpha$ causes a transient increase in luteal progesterone production, whereas chronic exposure results in inhibition of progesterone synthesis by bovine and pig luteal cells (Benyo and Pate, 1992; Pitzel et al., 1993; Townson and Pate, 1996; Wuttke et al., 1998). The antisteroidogenic effect of TNF- $\alpha$ is due, at least in part, to loss of StAR and LH receptor mRNA (Chen et al., 1999). Receptors for TNF- $\alpha$ have been localized on both small and large luteal cells, but the small cells possess a higher affinity receptor (Richards and Almond, 1994). The inhibitory effect of TNF- $\alpha$ on gonadotrophin-stimulated steroidogenesis is probably mediated via the type I TNF receptor (Roby et al., 
1999). In addition to direct effects on steroidogenic cells, some of the effects of TNF- $\alpha$ in the corpus luteum may be exerted on microvascular endothelial cells, which also contain TNF- $\alpha$ receptors (Richards and Almond, 1994; Okuda et al., 1999; Friedman et al., 2000); luteal endothelial cells undergo apoptosis in response to TNF- $\alpha$ (Friedman et al., 2000). Progesterone production by luteal cells is also inhibited by interleukin $1 \beta$ (IL-1 $\beta$ ) and interferon $\gamma($ IFN- $\gamma$; Nothnick and Pate, 1990; Fairchild and Pate, 1991). These three cytokines are extremely potent stimulators of luteal cell prostaglandin production (Nothnick and Pate, 1990; Fairchild and Pate, 1991; Benyo and Pate, 1992; Townson and Pate, 1996). The anti-steroidogenic effect of the three cytokines is not mediated by the increase in luteal prostaglandin production, because the effect is still apparent in the presence of a concentration of indomethacin that completely blocks the increase in prostaglandin synthesis (Fairchild and Pate, 1991). Thus, these two functional effects of cytokines on luteal cells are not interdependent.

\section{Cytokines as local initiators of cell death}

There is evidence that luteal regression occurs via apoptosis (Sawyer et al., 1990; Juengel et al., 1993), although Fraser et al. (1999) reported that apoptosis is not involved in luteal regression in marmosets. The factors that regulate the onset of apoptosis in the corpus luteum and the biological basis for the selection of specific cells to undergo apoptosis are not known. Gaytán et al. (1998b) demonstrated that prolactin and possibly progesterone are necessary for induction of apoptosis in the rat corpus luteum, but progesterone apparently inhibits apoptosis in the bovine corpus luteum (Rueda et al., 2000). Apoptosis is initiated by TNF- $\alpha$ in a number of types of cell, including luteal cells (Wuttke et al., 1997a; Petroff et al., 1999). In cultured bovine and murine luteal cells, TNF- $\alpha$ alone does not alter cell viability, but exerts a dose-dependent cytotoxic effect in the presence of IFN- $\gamma$ (Benyo and Pate, 1992; Jo et al., 1995a). This effect is similar to the cytotoxic effect of the combination of these two cytokines that has been demonstrated in pancreatic $\beta$ islet cells (Campbell et al., 1988; Rabinovitch et al., 1990) and thyroid cells (Weetman and Rees, 1988). As TNF- $\alpha$ and its receptors are present in the corpus luteum, it is possible that this cytokine induces apoptosis of the steroidogenic cells directly, possibly in this way mediating the luteolytic action of $\mathrm{PGF}_{2 \alpha}$.

Reactive oxygen species (ROS) are probably involved in damage of cells during luteal regression, and the generation of ROS may also have negative effects on steroidogenesis. Kato et al. (1997) reviewed this subject and noted that, although ROS do not initiate luteal regression, ROS may mediate downstream events in luteal regression that ultimately lead to the demise of the corpus luteum. Production of ROS is stimulated by $\mathrm{PGF}_{2 \alpha}$ and activated through the protein kinase C pathway (Sakka et al., 1997; Aten et al., 1998). However, Aten et al. (1998) reported that the ROS were generated primarily by non-steroidogenic cells during luteolysis, and suggested that this was a role of leucocytic cells in promoting rapid damage of the surrounding luteal cells. Progesterone can inhibit superoxide radical production by macrophages (Sugino et al., 1996), possibly protecting luteal cells from cellular damage before the decline in steroidogenesis. The high rate of steroidogenesis characteristic of a fully functional corpus luteum also results in substantial production of ROS. In addition to possible protection by progesterone and by endogenous antioxidants such as ascorbate, $\alpha$-tocopherol and $\beta$-carotene (Rapoport et al., 1998), luteotrophic hormones, such as prolactin and hCG, can increase enzymes that protect against ROS, such as manganese superoxide dismutase (Mn-SOD; Sugino et al., 1998a; Dharmarajan et al., 1999). The decline in Mn-SOD during regression of the corpus luteum (Rueda et al., 1995a) may increase the susceptibility of luteal cells to the ROS generated by activated resident immune cells. Finally, nitric oxide (NO) has also been implicated as a mediator of cell death during luteolysis (Olson et al., 1996). Inhibition of NO synthase results in an increase in progesterone production and extension of the duration of the oestrous cycle in cows (Jaroszewski and Hansel, 2000). IL-1 $\beta$ induced cytotoxicity in the rat ovary is mediated by NO (Ellman et al., 1993), and IFN- $\gamma$, in combination with either TNF- $\alpha$ or IL-1 $\beta$, stimulated NO production in cultured murine luteal cells (Jo et al., 1995b). However, inhibition of NO synthase did not decrease the cytotoxic effect of TNF- $\alpha$ + IFN- $\gamma$ (Jo et al., 1995b; Petroff et al., 1999).

Apoptosis can be initiated via the Fas-Fas ligand system. Fas is a transmembrane receptor that belongs to the TNF receptor family. When bound by Fas ligand, signal transduction pathways that result in apoptosis are activated. Fas has been implicated as a mediator of cell death during follicular atresia and cytokine-induced death of follicular cells (Quirk et al., 1998; Porter et al., 2000; Vickers et al., 2000). Both Fas and Fas ligand are present in the corpus luteum, and they both increase at the time of luteolysis (Roughton et al., 1999). Prolactin-induced apoptosis in rat luteal cells in vitro may be mediated by the Fas-Fas ligand system (Kuranaga et al., 1999). Quirk et al. (2000) demonstrated that TNF- $\alpha+$ IFN- $\gamma$ upregulate Fas mRNA in murine luteal cells, and increase the sensitivity of those cells to killing by Fas monoclonal antibody. Thus, immune cell cytokines may facilitate luteolysis by increasing Fas-Fas ligand-mediated cell killing. Removing immune cells from a suspension of luteal cells prevented prolactin-induced apoptosis (Kuranaga et al., 2000). These authors also found that Fas mRNA was expressed in luteal cells, whereas Fas ligand mRNA was expressed in the T lymphocytes found in the corpus luteum. They concluded that immune cells are required for Fas-mediated apoptosis during luteal regression. Therefore, a primary role of immune cells in the corpus luteum may be to activate the Fas transmembrane protein to initiate cell death. The proposed role of immune cells and cytokines in mediating the decline in steroidogenesis and initiating cell death is depicted (Fig. 2). 


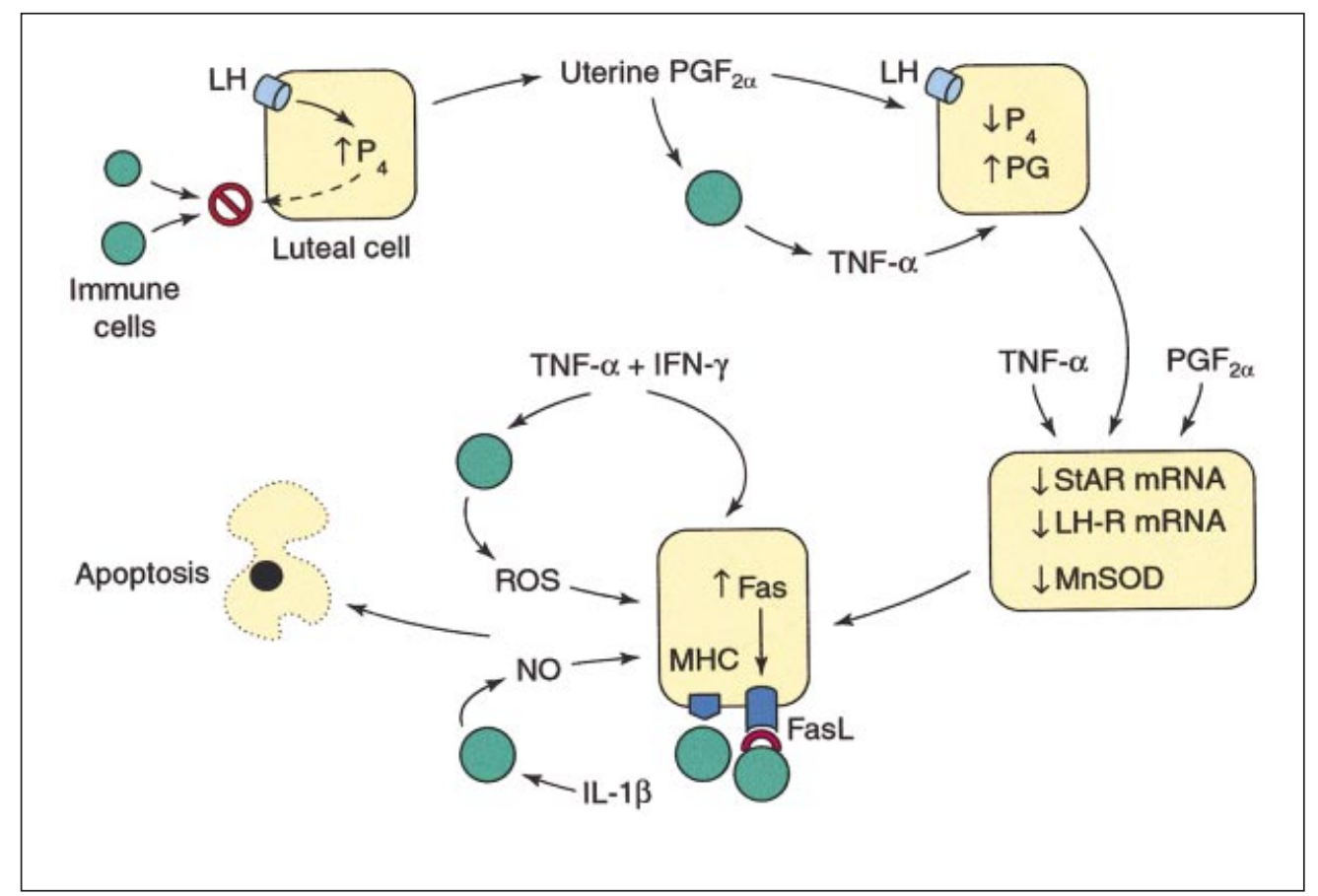

Fig. 2. Fully functional luteal cells make progesterone $\left(\mathrm{P}_{4}\right)$ in response to stimulation by gonadotrophin, such as LH. High concentrations of progesterone inhibit functions of immune cells and the cytokines they produce. In many species, uterine release of $\mathrm{PGF}_{2 \alpha}$ initiates luteolysis, and gonadotrophinstimulated steroidogenesis is acutely inhibited. Resident immune cells may be stimulated either directly or indirectly by $\mathrm{PGF}_{2 \alpha}$ to secrete cytokines. Tumour necrosis factor $\alpha$ (TNF- $\alpha$ ) further decreases progesterone production and stimulates synthesis of luteal prostaglandins. The decline in progesterone will be sustained as TNF- $\alpha$ decreases mRNA for steroidogenic acute regulatory protein (StAR) and LH receptor (LH-R). During luteolysis, there is a decline in manganese superoxide dismutase (MnSOD), which increases the susceptibility of luteal cells to reactive oxygen species (ROS). Continued exposure to TNF- $\alpha$ and interferon $\gamma$ (IFN- $\gamma$ ) induces expression of class II MHC and Fas molecules. Antigen presentation by $\mathrm{MHC}$ molecules activates lymphocytes and further production of cytokines. Recognition of Fas by Fas ligand (FasL) on lymphocytes initiates apoptosis of luteal cells. Activated lymphocytes produce ROS, and lymphocytes that are exposed to interleukin $1 \beta$ (IL-1 $\beta$ ) may produce nitric oxide (NO), causing further damage to adjacent luteal cells. These events culminate in apoptosis of steroidogenic cells and structural demise of the tissue.

\section{MHC molecules on luteal cells: recognition as non-self}

The major histocompatibility complex (MHC) genes encode cell surface glycoproteins that are critical to the recognition of cells by T lymphocytes as either self or nonself. The MHC molecules present small peptides of exogenous or endogenous origin to $\mathrm{T}$ lymphocytes. Peptides presented by class I MHC molecules are recognized by $\mathrm{CD} 8+\mathrm{T}$ lymphocytes. If appropriately stimulated, these cells show cytotoxic activity directed against the antigen-presenting cell. Class II MHC molecules and the associated peptides are recognized by CD4+ $\mathrm{T}$ lymphocytes. Activation of CD4+ cells results in clonal expansion of these cells and release of cytokines such as TNF- $\alpha$ and IFN- $\gamma$. Although presentation of peptides by class II molecules is generally restricted to professional antigen-presenting cells, such as macrophages and B cells, there are now numerous examples of somatic cell expression of class II molecules. This is usually indicative of a pathogenic state, and is a common feature of most autoimmune diseases (Eisenbarth, 1999). Both class I and class II MHC molecules may present self-peptides, thus eliciting an autoimmune response.

Luteal cells express both class I and class II MHC molecules (Fairchild and Pate, 1989; Khoury and Marshall, 1990; Kenny et al., 1991). Exposure of luteal cells to TNF- $\alpha$ or IFN- $\gamma$ increases the expression of class I MHC per cell, as well as the overall percentage of luteal cells expressing class I MHC molecules (Benyo and Pate, 1992). IFN- $\gamma$ treatment also results in a strong induction of class II MHC expression in cultured luteal cells (Fairchild and Pate, 1989). Expression of MHC molecules has also been examined on freshly isolated luteal cells collected from cows on days 6,10 and 18 of the oestrous cycle, representing developing, fully functional and early regressing corpora lutea, respectively (Benyo et al., 1991). 
As expected, class I MHC molecules are present on luteal cells, and their expression does not vary significantly across the oestrous cycle. In contrast, expression of class II MHC molecules is variable, depending on the functional state of the corpus luteum. In the developing corpus luteum, minimum expression of class II molecules is detected, but expression is increased in the mid-cycle corpus luteum. By day 18 of the oestrous cycle (just before luteal regression in cows), most of the small and large luteal cells show substantial class II MHC expression. Expression of class II molecules on luteal cells is also significantly increased when luteal regression is induced by $\mathrm{PGF}_{2 \alpha}$. In these studies, MHC-positive luteal cells were identified as steroidogenic cells by their size, as determined by flow cytometry (> $20 \mu \mathrm{m})$ and positive staining for the steroidogenic enzyme $3 \beta$-hydroxysteroid dehydrogenase. This finding led to the hypothesis that the demise of the corpus luteum may involve local autoimmune response mechanisms facilitated by increased expression of class II MHC molecules at the time of luteolysis (Benyo et al., 1991). Similar patterns of MHC expression have been observed in the sheep corpus luteum (Kenny et al., 1991). In both of these studies, MHC molecule expression was significantly lower in corpora lutea from pregnant animals compared with that in non-pregnant animals, consistent with a role for $\mathrm{MHC}$ molecules in luteal regression, and implying that there is a mechanism by which MHC expression in the corpus luteum is either modified or suppressed during maternal recognition of pregnancy.

There is also evidence that these MHC molecules are functional immunologically. Petroff et al. (1997) cocultured luteal cells with autologous $T$ cells and assessed $\mathrm{T}$ cell proliferation. It was observed that luteal cells are extremely effective stimulators of $\mathrm{T}$ cell proliferation, and the T cell proliferative response was greater in the presence of cells from regressing corpora lutea compared with that of cells from mid-cycle corpora lutea. Furthermore, the degree of T cell proliferation in the presence of luteal cells was 7.5fold greater than that observed when T cells were stimulated by professional antigen-presenting cells (mixed lymphocyte reaction), indicating that $\mathrm{T}$ cell stimulation by luteal cells is not due to minor contamination by resident macrophages. From these observations, it was suggested that luteal cells could serve as antigen-presenting cells, initiating a transient autoimmune response during luteolysis (Petroff et al., 1997). Autoimmunity is an immune response generated against self-antigens, which may occur as part of a physiological event. However, if allowed to continue, the autoimmunity may progress to a disorder, resulting in autoimmune disease, of which there are numerous examples (Bottazzo et al., 1986; Bellgrau and Eisenbarth, 1999). Normal expression of ovarian target antigens may develop into ovarian autoimmune disease (Hill et al., 1990).

The ability of somatic cells in the reproductive tract to act as antigen-presenting cells is not without precedent. Uterine epithelial and stromal cells can serve as antigen-presenting cells (Wira and Rossoll, 1995). These cells show MHC class
II-mediated antigen presentation, which varies with the oestrous cycle and appears to be regulated by steroid hormones (Wira and Rossoll, 1995; Wira et al., 2000). Thus, types of reproductive cell may be active stimulators of resident immune cells to facilitate responses necessary for normal function of the reproductive tissue.

\section{Disruption of the immune response}

Additional evidence for a role of immune cells in promoting luteolysis is found in experiments in which the immune system has been disrupted. Immunosuppression by dexamethasone blocked natural, but not $\mathrm{PGF}_{2 \alpha}$-induced, luteolysis in rats (Wang et al., 1993) and extended luteal function by an average of 10 days in cows (Kanchev et al., 1976). Experimental suppression of the immune system results in ovarian dysfunction in both rats (Bukovsky et al., 1977) and dairy cows (Alila and Hansel, 1984). Neonatal thymectomy results in severe ovarian dysgenesis, a model often used to study interactions between the immune system and the ovary (Michael et al., 1980), and corpora lutea do not regress normally in athymic nude mice (reviewed by Bukovsky et al., 1991). Possibly the most compelling evidence is that removal of macrophages by splenectomy results in a significant prolongation of luteal function in pseudopregnant rabbits (Nariai et al., 1995; Endo and Kanayama, 1998), the oestrous cycle is prolonged in granulocyte-macrophage colony-stimulating factor (GM-CSF)-deficient mice (Jasper et al., 2000), and dioestrus is extended in TNF type I receptor knockout mice (Roby et al., 1999). Finally, luteal regression after parturition in ewes progresses much less rapidly than at the end of the oestrous cycle, and large luteal cells are still present at day 15 after parturition (O'Shea and Wright, 1985). There must be active mechanisms during cyclic ovarian function to allow rapid deterioration of the corpus luteum, otherwise deterioration would occur more slowly, as is the case after parturition.

\section{Hypothesis II - immune cells protect surviving luteal cells as the corpus luteum regresses}

The widely recognized and documented increase in immune cells in the corpus luteum as it regresses has prompted many investigators to invoke these cells and their cytokine products as active participants in the destruction of luteal cells. This hypothesized role for immune cells has a considerable attractiveness, in that the appearance of large numbers of these cells in the regressing corpus luteum might offer a ready explanation for the physical destruction of luteal cells: the immune cells mediate or initiate changes in luteal cells that lead to death of luteal cells primarily by apoptosis. However, the appearance of immune cells at the time of regression can be viewed in another light: namely, that these cells function to control a potential inflammatory condition created by dead and dying cells, to provide a nurturing environment for the cells that have not died, and to participate in continuous restructuring as the corpus luteum loses mass. 
In women, the corpus luteum does not regress with a cataclysmic bang, but rather shows a gradual loss of progesterone production over a period of about 1 week (Thorneycroft, 1971). During this period of declining progesterone production, immune cells, primarily macrophages and lymphocytes, invade the human corpus luteum (Hameed et al., 1995; Best et al., 1996; Takaya et al., 1997). The corpus luteum is still present in the early follicular phase of the next menstrual cycle, and has abundant macrophages (Brännström et al., 1994). In cows (Kastelic et al., 1990; Peters et al., 1994) and other domestic species (Karsch et al., 1979), in which uterine prostaglandins appear to initiate the cascade of events leading to regression (McCracken et al., 1999; Niswender et al., 2000), the decrease in progesterone in the non-fertile cycle is more precipitous than that in women. However, as the bovine corpus luteum enters the period of declining progesterone production, lymphocytes are more abundant; at advanced stages of regression, macrophages are more abundant than at an earlier stage (Penny et al., 1999; Bauer et al., 2001). Thus, throughout the period during which progesterone secretion is declining, immune cells infiltrate the regressing corpus luteum, composed of dying and living luteal parenchymal cells. The above hypothesis holds that these immune cells are essential to contain a potential inflammatory condition, and possibly to provide local support for the surviving luteal cells until they are induced to die, leaving the corpus albicans.

\section{Steroidogenesis in the presence of immune cells}

What changes in steroidogenesis are observed when luteal cells are cultured in the presence of immune cells? Kirsch et al. (1981) cultured mouse luteal cells with either peritoneal macrophages or with macrophages derived from corpora lutea, and observed stimulation of progesterone and 20 $\alpha$-dihydroprogesterone production and accumulation over 3-5 days and 6-8 days of culture,. Human granulosa cells in the early stages of luteinization were cultured for 24 or $48 \mathrm{~h}$ with either peritoneal macrophages or blood monocytes, and in the presence of these cells, progesterone production and accumulation was increased. Furthermore, the increase in progesterone production and accumulation was positively related to concentrations of peritoneal macrophages (Halme et al., 1985). Naito and Takahashi (1988) cultured rat luteal cells with peritoneal macrophages and observed that, in the presence of macrophages, the secretion of progesterone and the ratio of progesterone:20 $\alpha$-dihydroprogesterone were maintained well above those of control cultures without macrophages. As macrophages alone did not produce steroids (data not shown), the authors concluded that macrophages can maintain progesterone secretion in luteal cells. Steroidogenesis was not inhibited in rat luteal cells co-cultured with splenic macrophages, and splenic macrophages increased the production of progesterone relative to $20 \alpha$ dihydroprogesterone in response to pituitary hormones
(Matsuyama et al., 1992). Castro et al. (1998) reported that human luteal cells from which leucocytes were removed produced higher amounts of progesterone in cell cultures, but less progesterone when stimulated with chorionic gonadotrophin. In the cultures, the production of oestradiol was not changed by the absence of leucocytes. Thus, most of the evidence from published studies indicates that macrophages artificially added to luteal cells in culture do not inhibit steroidogenic activity, and actually promote higher rates of steroid production or accumulation, or increase responsiveness to gonadotrophins. An important but unresolved question is whether the presence of macrophages was associated with higher survival rates for luteal cells in these cultures. Some reports have revealed that cytokines normally produced by macrophages and lymphocytes can have salutary effects on luteal or granulosa cells, including increased rates of steroidogenesis (Hughes et al., 1991; Chen et al., 1992; Ness and Kasson, 1995; Prakash et al., 1997) and increased expression of manganese superoxide dismutase that can protect mitochondria against oxygen radicals (Sugino et al., 1998b).

If macrophages and other immune cells function as supportive or protective cells in the dying corpus luteum, luteal tissue infiltrated with macrophages should retain its capacity for progesterone synthesis and secretion. This idea was tested in rabbits by Naftalin et al. (1997). In this report, an oestrogen withdrawal-replacement protocol was used to induce, experimentally, invasion of macrophages into the corpora lutea. Corpora lutea of the same age either with experimentally induced large numbers of macrophages or with small numbers of macrophages (control animals without oestradiol withdrawal-replacement) were incubated and progesterone was measured in the medium. Progesterone production and accumulation was maintained throughout $10 \mathrm{~h}$ of incubation and was not different; surviving luteal tissue heavily infiltrated with macrophages produced as much progesterone as luteal tissue with relatively few macrophages. A similar observation was made in rats (D. H. Townson, J. M. Bowen, D. G. Remick, J. S. Warren, P. L. Keyes, unpublished). Hypophysectomized rats with corpora lutea were either treated with prolactin to induce an invasion of macrophages into the corpora lutea or were treated with vehicle (controls). After 4 days, when the corpora lutea of prolactin-treated rats were heavily infiltrated with macrophages and were regressing (Bowen et al., 1996), the corpora lutea were removed, incubated for $10 \mathrm{~h}$, and progestin (20 $\alpha$-dihydroprogesterone plus progesterone) was measured in the conditioned medium. The regressing corpora lutea from prolactin-treated rats produced and accumulated significantly (four- to fivefold; $P$ $<0.01)$ more progestin per unit of wet tissue than did nonregressing corpora lutea of control rats. It is possible that the production of steroid by regressing corpora lutea in these two studies was underestimated as the data were corrected for wet tissue mass, which would include populations of immune cells. Correction based upon the amount of a known steroidogenic enzyme, such as $3 \beta$-hydroxysteroid 
dehydrogenase, would be revealing. The above data indicate that the presence of large numbers of macrophages in rabbit and rat luteal tissues is compatible with high rates of steroidogenesis by surviving luteal cells. Furthermore, Amsterdam et al. (1998) reported that steroidogenesis may be increased in the early stages of apoptosis. If it is assumed that luteal cells die progressively over a period of days, then a question arises as to the biological basis for selection of luteal cells to undergo apoptosis as the luteal phase progresses and winds down.

\section{Phagocytosis of cells and cell remnants}

A major characteristic of macrophages is the capacity for phagocytosis of cells that are damaged or dying (Johnston, 1988). In the corpus luteum, this particular activity may be very important for timely, non-inflammatory resolution of regression. Macrophages engaged in phagocytosis of luteal cells have been observed in guinea-pigs during postpartum regression of the corpus luteum (Paavola, 1979). In the human corpus luteum, a marker antigen considered to be relatively specific for phagocytosing macrophages increased markedly as the corpus luteum aged and regressed (Takaya et al., 1997). The corpus luteum regresses primarily through loss of cells by apoptosis (Juengel et al., 1993; Shikone et al., 1996; Rueda et al., 1997), and phagocytosis by macrophages is the final event for cells dying by apoptosis (Savill et al., 1993). Phagocytosis of cells may hold the important clue for the relatively benign process of luteal regression, also highlighting the critical role for macrophages. Evidence from other systems indicates that macrophages are stimulated to suppress their production of proinflammatory mediators, and to increase their production of anti-inflammatory cytokines through the act of ingesting apoptotic cells (Voll et al., 1997; Fadok et al., 1998; McDonald et al., 1999). Fadok et al. (1998) reported that the recognition and ingestion of apoptotic cells by macrophages stimulates macrophage production of anti-inflammatory mediators such as transforming growth factor $\beta 1$ (TGF- $\beta 1$ ), prostaglandin $E_{2}$ and platelet-activating factor, while inhibiting the production of eicosanoids and certain proinflammatory cytokines, such as TNF- $\alpha$ and interleukins. TGF- $\alpha$ is proposed to have an important autocrine action in this cascade. The uptake of apoptotic cells by macrophages also inhibits the synthesis and secretion of certain chemokines, macrophage inflammatory protein 2 (Mip-2) and Mip-1 $\alpha$, but not that of monocyte chemoattractant protein 1 (McDonald et al., 1999). Such a mechanism might allow for the selective recruitment of monocytes, which are very prevalent in the corpus luteum in association with expression of monocyte chemoattractant protein 1 (Townson et al., 1996; Penny, 2000).

The emphasis here is upon the speed and efficiency of macrophages to ingest apoptotic luteal cells and membranebound apoptotic cell bodies before the apoptotic cells lyse. As discussed by Savill (1997), an apoptotic cell disappears as a histologically recognized entity in only $1-2 \mathrm{~h}$ as a result of the rapid ingestion and degradation by phagocytes. Even a low rate of apoptosis results in speedy loss of tissue: assuming $1 \%$ of cells in a snapshot histological section are apoptotic, and a clearance time of $1 \mathrm{~h}$ by phagocytes, then $25 \%$ of cells will have disappeared in $24 \mathrm{~h}$ (Savill, 1997). If apoptotic cells were not cleared quickly, and allowed to lyse, this would represent a necrosis scenario, in which potentially noxious cell contents released into the interstitial space potentially could lead to an inflammatory condition. If this happened in the corpus luteum, inflammatory changes would pose a peril to surrounding ovarian tissues, including the oocytes. This general concept is highlighted by Savill (1997) and Green and Beere (2000), who refer to the protective and injury-limiting potential of phagocytosis of apoptotic cells in contrast to necrosis. However, it cannot be excluded that some necrosis occurs in luteal regression, particularly in experiments in which regression is induced prematurely and acutely by injections of $\mathrm{PGF}_{2 \alpha}$ or in which luteotrophic support is withdrawn, as illustrated in reports by Rueda et al. (1995b) and Fraser et al. (1995). The experimental induction of acute, premature luteal regression might be expected to cause a sudden surfeit of dead and dying cells, before the arrival of sufficient numbers of monocytes and macrophages, leading to some necrosis. Finally, it should be noted that the hormonal milieu in the corpus luteum might be highly conducive to increased phagocytic activity by macrophages. A number of reports have highlighted the effects of steroids on macrophages (Nicol et al., 1965; Vernon-Roberts, 1969; Chao et al., 1995; Miller and Hunt, 1996), and the evidence indicates that oestrogen has a marked stimulatory effect on the phagocytic activity of macrophages (Nicol et al., 1965; Vernon-Roberts, 1969) and that the action of oestrogen is not inhibited by progesterone (Nicol et al., 1965). Higher oestrogen concentrations, which would be expected in the non-regressing corpus luteum, particularly in those species in which the corpus luteum expresses aromatase (Elbaum and Keyes, 1976; Stouffer et al., 1980), may be inhibitory to the production of proinflammatory mediators in the corpus luteum, as has been reported in isolated monocytes and macrophages (Polan et al., 1989; reviewed by Miller and Hunt, 1996). The oestrogen content of the corpus luteum, coupled with the presence of oestrogen receptors in macrophages (Gulshan et al., 1990), represent potentially favorable conditions for anti-inflammatory activities of macrophages.

\section{Role of immune cells in maternal recognition of pregnancy}

If hypothesis I is correct, a signal must be present during maternal recognition of pregnancy that either reduces production of chemoattractant molecules or suppresses the response of the immune cells to them. During the oestrous cycle, lymphocytes and macrophages are recruited into the corpus luteum, which is destined to regress; this recruitment 
of immune cells does not occur at the similar time of early pregnancy (Lobel and Levy, 1968; Bagavandoss et al., 1990). Activation of resident immune cells might also be compromised during pregnancy, because expression of $\mathrm{MHC}$ molecules is lower in corpora lutea from pregnant versus non-pregnant animals (Benyo et al., 1991; Kenny et al., 1991). Thus, there must be a mechanism by which recruitment and activation of immune cells is suppressed during early pregnancy. As the uterus prepares to accept the fetal allograft, mechanisms to accomplish this may also influence luteal survival. Takiguchi et al. (2000) observed that luteal progesterone and superoxide dismutases were increased by placental supernatant. They speculated that this was a component of the rescue of the corpus luteum that occurs during maternal recognition of pregnancy. The uterus of pregnant ewes produces proteins that inhibit lymphocyte proliferation (Skopets and Hansen, 1993), but it is unknown whether these proteins travel to the ovary or whether similar proteins are produced coincidentally in the ovary. A trophoblast-derived molecule that suppresses IFN$\gamma$-induced MHC class II expression has been described (Peyman, 1999). This molecule was also expressed in the ovary, raising the possibility that it is involved in preventing the increase in $\mathrm{MHC}$ expression in the corpus luteum during maternal recognition of pregnancy.

The localized immune response that is initiated at the time of luteolysis may also be prevented in early pregnancy by the high concentrations of progesterone within the corpus luteum. Progesterone is a very effective immunosuppressive agent owing to its ability to inhibit lymphocyte proliferation and function (reviewed by Siiteri and Stites, 1982; Grossman, 1984; Kelly, 1994). In addition to suppressing lymphocyte function, progesterone inhibits cytokine action on luteal cells directly. Stimulation of prostaglandin production by cytokines is completely inhibited by progesterone and, when combined with IFN $-\gamma$, progesterone can suppress cytokine-induced expression of $\mathrm{MHC}$ molecules on luteal cells (Pate, 1995). Thus, the decline in intraluteal progesterone concentrations initiated by uterine $\mathrm{PGF}_{2 \alpha}$ may release the immune cells from the suppressive effects of progesterone, and allow cytokines to exert their effects on luteal cells. With maintenance of progesterone during maternal recognition of pregnancy, suppression of immune cells would be sustained.

\section{Conclusions}

Immune cells are recruited into the corpus luteum as it ages and regresses, and these cells probably have important physiological roles, particularly during the regression phase. Most experiments have been conducted in vitro to test the hypothesis that immune cells are involved directly in inhibition of steroidogenesis and destruction of the tissue. The data from a number of reports are consistent with this hypothesis. However, more definitive experiments to test this hypothesis in vivo have yet to be performed. Furthermore, the results of some experiments have led to an alternative hypothesis, that immune cells nurture the surviving luteal cells as the corpus luteum regresses as a result of apoptotic events. This may be true during luteolysis, as well as during luteinization and luteal rescue in early pregnancy. It may yet be determined that immune cells are integral components of most of the functional and structural changes that occur throughout the lifespan of the corpus luteum. Whether the role of immune cells is to support or destroy luteal cells may depend on the balance of immune cells present, their activation state, and the milieu of cytokines and hormones present at a particular time.

\section{References}

Key references are identified by asterisks.

Alila HL and Hansel W (1984) Induction of lymphopenia causes luteal dysfunction in cattle Biology of Reproduction 31 609-616

Amsterdam A, Dantes A, Hosokawa K, Schere-Levy CP, Kotsuji F and Aharoni D (1998) Steroid regulation during apoptosis of ovarian follicular cells Steroids 63 314-318

Aten RF, Kolodecik TR, Rossi MJ, Debusscher C and Behrman HR (1998) Prostaglandin $\mathrm{F}_{2 \alpha}$ treatment in vivo, but not in vitro, stimulates protein kinase $\mathrm{C}$-activated superoxide production by nonsteroidogenic cells of the rat corpus luteum Biology of Reproduction 59 1069-1076

Bagavandoss P, Kunkel SL, Wiggins RC and Keyes PL (1988) Tumor necrosis factor (TNF- $\alpha$ ) production and localization of macrophages and T lymphocytes in the rabbit corpus luteum Endocrinology 122 1185-1187

Bagavandoss P, Wiggins RC, Kunkel SL, Remick DG and Keyes PL (1990) Tumor necrosis factor production and accumulation of inflammatory cells in the corpus luteum of pseudopregnancy and pregnancy in rabbits Biology of Reproduction 42 367-376

Bauer M, Reibiger I and Spanel-Borowski K (2001) Leukocyte proliferation in the bovine corpus luteum Reproduction 121 297-305

Behrman HR, Aten RF and Pepperell JR (1991) Cell-to-cell interactions in luteinization and luteolysis. In Ovarian Endocrinology pp 190-225 Ed. SG Hillier. Blackwell Scientific Publication, London

Bellgrau D and Eisenbarth GS (1999) Immunobiology of autoimmunity. In Endocrine and Organ Specific Autoimmunity pp 1-18 Ed. GS Eisenbarth. RG Landes Company, Austin

Benyo DL and Pate JL (1992) Tumor necrosis factor $\alpha$ alters bovine luteal cell synthetic capacity and viability Endocrinology 130 854-860

*Benyo D, Haibel GK, Laufman HB and Pate JL (1991) Expression of major histocompatibility complex antigens on the bovine corpus luteum during estrous cycle, luteolysis, and early pregnancy Biology of Reproduction 45 229-234

Best CL, Pudney J, Welch WR, Burger N and Hill JA (1996) Localization and characterization of white blood cell populations within the human ovary throughout the menstrual cycle and menopause Human Reproduction 11 790-797

Bottazzo GF, Todd I, Mirakian R, Belfiore A and Pujol-Borrell R (1986) Organ-specific autoimmunity: a 1986 overview Immunological Reviews 94 137-169

Bowen JM, Keyes PL, Warren JS and Townson DH (1996) Prolactininduced regression of the rat corpus luteum: expression of monocyte chemoattractant protein-1 and invasion of macrophages Biology of Reproduction 54 1120-1127 Erratum (1996) 55224

Bowen JM, Towns R, Warren JS and Keyes PL (1999) Luteal regression in the normally cycling rat: apoptosis, monocyte chemoattractant protein1 , and inflammatory cell involvement Biology of Reproduction 60 740-746

Brännström M, Pascoe V, Norman RJ and McClure N (1994) Localization of leukocyte subsets in the follicle wall and in the corpus luteum throughout the human menstrual cycle Fertility and Sterility 61 488-495

Bukovsky A and Presl J (1979) Ovarian function and the immune system Medical Hypotheses 5 415-436 
Bukovsky A, Presl J, Kiabex Z and Bednarick T (1977) Ovarian function in adult rats treated with antithymocyte serum Experientia 33 280-281

Bukovsky A, Michael SD and Presl J (1991) Cell-mediated and neural control of morphostasis Medical Hypotheses 36 261-268

Campbell IC, Iscaro A and Harrison LC (1988) IFN- $\gamma$ and TNF- $\alpha$. Cytotoxicity to murine islets of Langerhans Journal of Immunology 141 2325-2329

Castro A, Castro O, Troncoso JL, Kohen P, Simon C, Vega M and Devoto L (1998) Luteal leukocytes are modulators of the steroidogenic process of human mid-luteal cells Human Reproduction 13 1584-1589

Chao T-C, Van Alten PJ, Greager JA and Walter RJ (1995) Steroid sex hormones regulate the release of tumor necrosis factor by macrophages Cellular Immunology $\mathbf{1 6 0} 43-49$

Chen TT, Lane TA, Doody MC and Caudle MR (1992) The effect of peritoneal macrophage-derived factor(s) on ovarian progesterone secretion and LH receptors: the role of calcium American Journal of Reproductive Immunology 28 43-50

Chen Y, Feng Q and Liu Y (1999) Expression of the steroidogenic acute regulatory protein and luteinizing hormone receptor and their regulation by tumor necrosis factor- $\alpha$ in rat corpora lutea Biology of Reproduction $60419-427$

Dharmarajan AM, Hisheh S, Singh B, Parkinson S, Tilly KI and Tilly JL (1999) Antioxidants mimic the ability of chorionic gonadotropin to suppress apoptosis in the rabbit corpus luteum in vitro: a novel role for superoxide dismutase in regulating bax expression Endocrinology 140 $2555-2561$

Eisenbarth GS (1999) Endocrine and Organ Specific Autoimmunity RG Landes Company, Austin

Elbaum DJ and Keyes PL (1976) Synthesis of 17ß-estradiol by isolated ovarian tissues of the pregnant rat: aromatization in the corpus luteum Endocrinology 99 573-579

Ellman C, Corbett JA, Misko TP, McDaniel M and Beckerman KP (1993) Nitric oxide mediates interleukin-1 $\beta$-induced cellular cytotoxicity in the rat ovary Journal of Clinical Investigation 92 3053-3056

*Endo T and Kanayama K (1998) Effects of splenectomy on luteal function in pseudopregnant rabbits Journal of International Medical Research 26 93-97

Fadok VA, Bratton DL, Konowal A, Freed PW, Westcott JY and Henson PM (1998) Macrophages that have ingested apoptotic cells in vitro inhibit proinflammatory cytokine production through autocrine/paracrine mechanisms involving TGF- $\alpha, \mathrm{PGE}_{2}$, and PAF Journal of Clinical Investigation 101 890-898

Fairchild DL and Pate JL (1989) Interferon- $\gamma$ induction of major histocompatibility complex antigens on cultured bovine luteal cells Biology of Reproduction $40453-457$

Fairchild DL and Pate JL (1991) Modulation of bovine luteal cell synthetic capacity by interferon-gamma Biology of Reproduction 44 357-363

Fraser HM, Lunn SF, Cowen GM and Illingworth PJ (1995) Induced luteal regression in the primate: evidence for apoptosis and changes in c-myc protein Journal of Endocrinology 147 131-137

Fraser HM, Lunn SF, Harrison DJ and Kerr JB (1999) Luteal regression in the primate: different forms of cell death during natural and gonadotropinreleasing hormone antagonist or prostaglandin analogue-induced luteolysis Biology of Reproduction 61 1468-1479

Friedman A, Weiss S, Levy N and Meidan R (2000) Role of tumor necrosis factor- $\alpha$ and its type I receptor in luteal regression: induction of programmed cell death in bovine corpus luteum-derived endothelial cells Biology of Reproduction 63 1905-1912

Gaytán F, Morales C, Bellido C, Aguilar E and Sánchez-Criado JE (1997) Role of prolactin in the regulation of macrophages and in the proliferative activity of vascular cells in newly formed and regressing rat corpora lutea Biology of Reproduction 57 478-486

Gaytán F, Morales C, García-Pardo L, Reymundo C, Bellido C and SánchezCriado JE (1998a) Macrophages, cell proliferation, and cell death in the human menstrual corpus luteum Biology of Reproduction 59 417-425

Gaytán F, Bellido C, Morales C and Sánchez-Criado JE (1998b) Both prolactin and progesterone in proestrus are necessary for the induction of apoptosis in the regressing corpus luteum of the rat Biology of Reproduction 59 1200-1206
Green DR and Beere HM (2000) Apoptosis. Gone but not forgotten Nature $40528-29$

Grossman CJ (1984) Regulation of the immune system by sex steroids Endocrine Reviews 5 435-455

Gulshan S, McCruden AB and Stimson WH (1990) Oestrogen receptors in macrophages Scandinavian Journal of Immunology 31 691-697

Halme J, Hammond MG, Syrop CH and Talbert LM (1985) Peritoneal macrophages modulate human granulosa-luteal cell progesterone production Journal of Clinical Endocrinology and Metabolism 61 912-916

Hill JA, Welch WR, Faris HM and Anderson DJ (1990) Induction of class II major histocompatibility complex antigen expression in human granulosa cells by interferon gamma: a potential mechanism contributing to autoimmune ovarian failure American Journal of Obstetrics and Gynecology 162 534-540

Hameed A, Fox WM, Kurman RJ, Hruban RH and Podack ER (1995) Perforin expression in human cell-mediated luteolysis International Journal of Gynecological Pathology 14 151-157

Hughes FM, Jr, Pringle CM and Gorospe WC (1991) Production of progestin-stimulatory factor(s) by enriched populations of rat $\mathrm{T}$ and $\mathrm{B}$ lymphocytes Biology of Reproduction 44 922-926

Hume DA, Halpin D, Charlton H and Gordon S (1984) The mononuclear phagocyte system of the mouse defined by immunohistochemical localization of antigen F4/80: macrophages of endocrine organs Proceedings National Academy of Sciences USA 81 4174-4177

Hutchinson JS and Zeleznik AJ (1985) The corpus luteum of the primate menstrual cycle is capable of recovery from a transient withdrawal of pituitary gonadotropin support Endocrinology 117 1043-1049

Jaroszewski JJ and Hansel W (2000) Intraluteal administration of a nitric oxide synthase blocker stimulates progesterone and oxytocin secretion and prolongs the life span of the bovine corpus luteum Proceedings of the Society of Experimental Biology and Medicine 224 50-55

Jasper MJ, Robertson SA, Van der Hoek KH, Bonello N, Brännström M and Norman RJ (2000) Characterization of ovarian function in granulocyte-macrophage colony-stimulating factor-deficient mice Biology of Reproduction 62 704-713

Jenkin G, Gemmell RT and Thorburn GD (1984) Induction of transient functional luteolysis in cyclic sheep by a $3 \beta$-hydroxysteroid dehydrogenase inhibitor Journal of Endocrinology 100 61-66

Ji I, Slaughter RG, Ellis JA, Ji TH and Murdoch WJ (1991) Analyses of ovine corpora lutea for tumor necrosis factor mRNA and bioactivity during prostaglandin-induced luteolysis Molecular and Cellular Endocrinology $8177-80$

Jo T, Tomiyama T, Ohashi K, Saji F, Tanizawa O, Ozaki M, Yamamoto R, Yamamoto T, Nishizawa Y and Terada N (1995a) Apoptosis of cultured mouse luteal cells induced by tumor necrosis factor-alpha and interferon-gamma Anatomical Record 241 70-76

Jo T, Terada N, Takauchi Y, Saji F, Nishizawa Y, Tanaka S and Kosaka H (1995b) Cytotoxic actions of cytokines on cultured mouse luteal cells are independent of nitric oxide Journal of Steroid Biochemistry and Molecular Biology 55 291-296

Johnston RB, Jr (1988) Monocytes and macrophages New England Journal of Medicine 318 747-752

Juengel JL, Garverick HA, Johnson AL, Youngquist RS and Smith MF (1993) Apoptosis during luteal regression in cattle Endocrinology 132 249-254

Kanchev LN, Dobson H, Ward WR and Fitzpatrick RJ (1976) Concentration of steroids in bovine peripheral plasma during the oestrous cycle and the effect of betamethasone treatment Journal of Reproduction and Fertility 48 341-345

Karsch FJ, Foster DL, Legan SJ, Ryan KD and Peter GK (1979) Control of the preovulatory endocrine events in the ewe: interrelationship of estradiol, progesterone, and luteinizing hormone Endocrinology 105 421-426

Kastelic JP, Bergfelt DR and Ginther OJ (1990) Relationship between ultrasonic assessment of the corpus luteum and plasma progesterone concentration in heifers Theriogenology 33 1269-1278

Kato H, Sugino N, Takiguchi S, Kashida S and Nakamura Y (1997) Roles of reactive oxygen species in the regulation of luteal function Reviews of Reproduction 2 81-83

Kelly RW (1994) Pregnancy maintenance and parturition: the role of 
prostaglandin in manipulating the immune and inflammatory response Endocrine Reviews 15 684-706

Kenny N, Herman JR, Barisas BG and Roess DA (1991) Flow cytometric analysis of class I and II MHC antigens on ovine luteal cell types. In Signaling Mechanisms and Gene Expression in the Ovary pp 467-472 Ed. G Gibori. Springer-Verlag, New York

Khoury EL and Marshall LA (1990) Luteinization of human granulosa cells in vivo is associated with expression of MHC class II antigens Cell and Tissue Research 262 217-224

Kirsch TM, Friedman AC, Vogel RL and Flickinger GL (1981) Macrophages in corpora lutea of mice: characterization and effects on steroid secretion Biology of Reproduction 25 629-638

Kondo H, Maruo T and Mochizuki M (1995) Immunohistochemical evidence for the presence of tumor necrosis factor-alpha in the infant and adult human ovary Endocrine Journal 42 771-780

Kuranaga E, Kanuka H, Bannai M, Suzuki M, Nishihara $M$ and Takahashi M (1999) Fas/Fas ligand system in prolactin-induced apoptosis in rat corpus luteum: possible role of luteal immune cells Biochemical and Biophysical Research Communications 260 167-173

Kuranaga E, Kanuka H, Furuhata Y, Yonezawa T, Suzuki M, Nishihara M and Takahashi M (2000) Requirement of the Fas ligand-expressing luteal immune cells for regression of corpus luteum FEBS Letters 472 137-142

Lobel BL and Levy E (1968) Enzymatic correlates of development, secretory function and regression of follicles and corpora lutea in the bovine ovary. II. Formation, development and involution of corpora lutea Acta Endocrinologica 59 Supplement 132 35-63

McCracken JA, Custer EE and Lamsa JC (1999) Luteolysis: a neuroendocrine-mediated event Physiological Reviews 79 263-323

McDonald PP, Fadok VA, Bratton D and Henson PM (1999) Transcriptional and translational regulation of inflammatory mediator production by endogenous TGF- $\alpha$ in macrophages that have ingested apoptotic cells Journal of Immunology $\mathbf{1 6 3}$ 6164-6172

Matsuyama S, Shiota K, Tachi C, Nishihara M and Takahashi M (1992) Splenic macrophages enhance prolactin and luteinizing hormone action in rat luteal cell cultures Endocrinologica Japonica 39 51-57

Michael SD, Taguchi $\mathbf{O}$ and Nishizuka $\mathbf{Y}$ (1980) Effect of neonatal thymectomy on ovarian development and plasma $\mathrm{LH}, \mathrm{FSH}, \mathrm{GH}$ and PRL in the mouse Biology of Reproduction 22 343-350

Miller L and Hunt JS (1996) Sex steroid hormones and macrophage function Life Sciences 59 1-14

Milvae RA (2000) Inter-relationships between endothelin and prostaglandin $\mathrm{F}_{2 \alpha}$ in corpus luteum function Reviews of Reproduction $\mathbf{5}$ 1-5

Miyamoto Y, Skarzynski DJ and Okuda K (2000) Is tumor necrosis factor- $\alpha$ a trigger for the initiation of endometrial prostaglandin $F_{2 \alpha}$ release at luteolysis in cattle Biology of Reproduction 62 1109-1115

Murdoch WJ (1987) Treatment of sheep with prostaglandin $F_{2 \alpha}$ enhances production of a luteal chemoattractant for eosinophils American Journal of Reproductive Immunology and Microbiology 15 52-56

*Naftalin DM, Bove SE, Keyes PL and Townson DH (1997) Estrogen withdrawal induces macrophage invasion in the rabbit corpus luteum Biology of Reproduction $\mathbf{5 6}$ 1175-1180

Naito K and Takahashi M (1988) The effects of peritoneal macrophages on monolayered luteal cell progestin secretion in the rat Endocrinologica Japonica 35 439-446

Nariai K, Kanayama K, Endo T and Tsukise A (1995) Effects of splenectomy on luteolysis in pseudopregnant rabbits Journal of Veterinary Medical Science $\mathbf{5 7}$ 503-505

Ness JM and Kasson BG (1995) Stimulation of rat granulosa cell progesterone production but not other differentiated functions by a splenocyte-derived factor Journal of Reproduction and Fertility 105 125-133

Nicol T, Vernon-Roberts B and Quantock DC (1965) The influence of various hormones on the reticulo-endothelial system: endocrine control of body defense Journal of Endocrinology 33 365-383

*Niswender GD, Juengel JL, Silva PJ, Rollyson MK and McIntush EW (2000) Mechanisms controlling the function and life span of the corpus luteum Physiological Reviews 80 1-29

Nothnick WB and Pate JL (1990) Interleukin-1 $\beta$ is a potent stimulator of prostaglandin synthesis in bovine luteal cells Biology of Reproduction 43 898-903
Okuda K, Sakumoto R, Uenoyama Y, Berisha B, Miyamoto A and Schams D (1999) Tumor necrosis factor- $\alpha$ receptors in microvascular endothelial cells from bovine corpus luteum Biology of Reproduction 61 1017-1022

Olson KK and Townson DH (2000) Prolactin-induced expression of intercellular adhesion molecule-1 and the accumulation of monocytes/macrophages during regression of the rat corpus luteum Biology of Reproduction 62 1571-1578

Olson LM, Jones-Burton CM and Jablonka-Shariff A (1996) Nitric oxide decreases estradiol synthesis of rat luteinized ovarian cells: possible role for nitric oxide in functional luteal regression Endocrinology 137 3531-3539

*O'Shea JD and Wright PJ (1985) Regression of the corpus luteum of pregnancy following parturition in the ewe Acta Anatomica 122 69-76

Paavola LG (1979) The corpus luteum of the guinea pig. IV. Fine structure of macrophages during pregnancy and postpartum luteolysis and the phagocytosis of luteal cells American Journal of Anatomy 154 337-364

Pate JL (1995) Involvement of immune cells in regulation of ovarian function Journal of Reproduction and Fertility Supplement 49 365-377

Pate JL and Condon WA (1984) Effects of prostaglandin $F_{2 \alpha}$ on agonistinduced progesterone production in cultured bovine luteal cells Biology of Reproduction 31 427-435

Pate JL and Nephew KP (1988) Effects of in vivo and in vitro administration of prostaglandin $\mathrm{F}_{2 \alpha}$ on lipoprotein utilization in cultured bovine luteal cells Biology of Reproduction 38 568-576

Penny LA (2000) Monocyte chemoattractant protein-1 in luteolysis Reviews of Reproduction 5 63-66

Penny LA, Armstrong DG, Baxter G, Hogg C, Kindahl H, Bramley T, Watson ED and Webb $\mathbf{R}$ (1998) Expression of monocyte chemoattractant protein-1 in the bovine corpus luteum around the time of natural luteolysis Biology of Reproduction 59 1464-1469

Penny LA, Armstrong D, Bramley TA, Webb R, Collins RA and Watson ED (1999) Immune cells and cytokine production in the bovine corpus luteum throughout the oestrous cycle and after induced luteolysis Journal of Reproduction and Fertility 115 87-96

Peters KE, Bergfeld EG, Cupp AS et al. (1994) Luteinizing hormone has a role in development of fully functional corpora lutea $(\mathrm{CL})$ but is not required to maintain CL function in heifers Biology of Reproduction $\mathbf{5 1}$ $1248-1254$

Petroff M, Coggeshall KM, Jones LS and Pate JL (1997) Bovine luteal cells elicit major histocompatibility complex class II-dependent T-cell proliferation Biology of Reproduction 57 887-893

Petroff MG, Petroff BK and Pate JL (1999) Expression of cytokine messenger ribonucleic acids in the bovine corpus luteum Endocrinology $\mathbf{1 4 0}$ 1018-1021

Peyman JA (1999) Repression of major histocompatibility complex genes by a human trophoblast ribonucleic acid Biology of Reproduction $6023-31$

Pitzel L, Jarry H and Wuttke W (1993) Effects and interaction of prostaglandin $\mathrm{F}_{2 \alpha}$ oxytocin and cytokines on steroidogenesis of porcine luteal cells Endocrinology 132 751-756

Polan ML, Loukides J, Nelson P, Carding S, Diamond M, Walsh A and Bottomly K (1989) Progesterone and estradiol modulate interleukin-1 $\beta$ messenger ribonucleic acid levels in cultured human peripheral monocytes Journal of Clinical Endocrinology and Metabolism 69 1200-1206

Porter DA, Vickers SL, Cowan RG, Huber SC and Quirk SM (2000) Expression and function of Fas antigen vary in bovine granulosa and theca cells during ovarian follicular development and atresia Biology of Reproduction 62 62-66

Prakash BS, Pedina J, Steiner A and Wuttke W (1997) Demonstration of luteotrophic responses of human recombinant gamma interferon in porcine corpora lutea using an in vivo microdialysis system Journal of Steroid Biochemistry and Molecular Biology 63 189-194

Quirk SM, Porter DA, Huber SC and Cowan RG (1998) Potentiation of Fasmediated apoptosis of murine granulosa cells by interferon- $\gamma$, tumor necrosis factor- $\alpha$, and cycloheximide Endocrinology 139 4860-4869

Quirk SM, Harman RM, Huber SC and Cowan RG (2000) Responsiveness of mouse corpora luteal cells to Fas antigen (CD95)-mediated apoptosis Biology of Reproduction 63 49-56 
Rabinovitch A, Baquerizo H and Sumoski W (1990) Cytotoxic effects of cytokines on islet $\beta$ cells: evidence for involvement of eicosanoids Endocrinology 126 67-71

Rapoport R, Sklan D, Wolfenson D, Shaham-Albalancy A and Hanukoglu I (1998) Antioxidant capacity is correlated with steroidogenic status of the corpus luteum during the bovine estrous cycle Biochimica et Biophysica Acta 1380 133-140

Richards RG and Almond GW (1994) Identification and distribution of tumor necrosis factor- $\alpha$ receptors in pig corpora lutea Biology of Reproduction 51 1285-1291

Roby KF and Terranova PF (1989) Localization of tumor necrosis factor (TNF) in the rat and bovine ovary using immunocytochemistry and cell blot: evidence for granulosal production. In Growth Factors and the Ovary pp 273-278 Ed. AN Hirshfield. Plenum Press, New York

Roby KF, Weed J, Lyles R and Terranova PF (1990) Immunological evidence for a human ovarian tumor necrosis factor- $\alpha$ Journal of Clinical Endocrinology and Metabolism 71 1096-1102

Roby KF, Son D and Terranova PF (1999) Alterations of events related to ovarian function in tumor necrosis factor receptor type I knockout mice Biology of Reproduction 61 1616-1621

Roughton SA, Lareu RR, Bittles AH and Dharmarajan AM (1999) Fas and Fas ligand messenger ribonucleic acid and protein expression in the rat corpus luteum during apoptosis-mediated luteolysis Biology of Reproduction 60 797-804

Rueda BR, Tilly KI, Hansen TR, Hoyer PB and Tilly JL (1995a) Expression of superoxide dismutase, catalase and glutathione peroxidase in the bovine corpus luteum: evidence supporting a role for oxidative stress in luteolysis Endocrine 3 227-232

Rueda BR, Wegner JA, Marion SL, Wahlen DD and Hoyer PB (1995b) Internucleosomal DNA fragmentation in ovine luteal tissue associated with luteolysis: in vivo and in vitro analyses Biology of Reproduction 52 305-312

Rueda BR, Tilly KI, Botros IW, Jolly PD, Hansen TR, Hoyer PB and Tilly JL (1997) Increased bax and interleukin-1 $\beta$-converting enzyme messenger ribonucleic acid levels coincide with apoptosis in the bovine corpus luteum during structural regression Biology of Reproduction 56 186-193

Rueda BR, Hendry IR, Hendry WJ, III, Stormshak F, Slayden OD and Davis JS (2000) Decreased progesterone levels and progesterone receptor antagonists promote apoptotic cell death in bovine luteal cells Biology of Reproduction 62 269-276

Sakka E, Rae M, Aitken J and Bramley T (1997) Protein kinase C- and $\mathrm{Ca}^{2+}$ ionophore-stimulated production of reactive oxygen species in mechanically dispersed isolated bovine luteal cells Biology of Reproduction $\mathbf{5 7}$ 428-435

Savill J (1997) Recognition and phagocytosis of cells undergoing apoptosis British Medical Bulletin 53 491-508

Savill J, Fadok V, Henson P and Haslett C (1993) Phagocyte recognition of cells undergoing apoptosis Immunology Today 14 131-136

Sawyer HR, Niswender KD, Braden TD and Niswender GD (1990) Nuclear changes in ovine luteal cells in response to PGF $_{2 \alpha}$ Domestic Animal Endocrinology $7229-238$

Shaw DW and Britt JH (1995) Concentrations of tumor necrosis factor alpha and progesterone within the bovine corpus luteum sampled by continuous-flow microdialysis during luteolysis in vivo. Biology of Reproduction 53 847-854

Shikone T, Yamoto M, Kokawa K, Yamashita K, Nishimori K and Nakano R (1996) Apoptosis of human corpora lutea during cyclic luteal regression and early pregnancy Journal of Clinical Endocrinology and Metabolism $812376-2380$

Siiteri PK and Stites DP (1982) Immunologic and endocrine interrelationships in pregnancy Biology of Reproduction 26 1-14

Skopets B and Hansen PJ (1993) Identification of the predominant proteins in uterine fluids of unilaterally pregnant ewes that inhibit lymphocyte proliferation Biology of Reproduction 49 997-1007

Stouffer RL, Bennett LA and Hodgen GD (1980) Estrogen production by luteal cells isolated from rhesus monkeys during the menstrual cycle: correlation with spontaneous luteolysis Endocrinology 106 519-525

Sugino N, Shimamura K, Tamura H, Ono M, Nakamura Y, Ogino K and
Kato H (1996) Progesterone inhibits superoxide radical production by mononuclear phagocytes in pseudopregnant rats Endocrinology 137 749-754

Sugino N, Hirosawa-Takamori M, Zhong L, Telleria CM, Shiota K and Gibori G (1998a) Hormonal regulation of copper-zinc superoxide dismutase and manganese superoxide dismutase messenger ribonucleic acid in the rat corpus luteum: induction by prolactin and placental lactogens Biology of Reproduction 59 599-605

Sugino N, Telleria CM and Gibori G (1998b) Differential regulation of copper-zinc superoxide dismutase and manganese superoxide dismutase in the rat corpus luteum: induction of manganese superoxide dismutase messenger ribonucleic acid by inflammatory cytokines Biology of Reproduction $\mathbf{5 9} 208-215$

Takaya R, Fukaya T, Sasano H, Suzuki T, Tamura M and Yajima A (1997) Macrophages in normal cycling human ovaries: immunohistochemical localization and characterization Human Reproduction 127 1508-1512

Takiguchi S, Sugino N, Kashida S, Yamagata Y, Nakamura Y and Kato H (2000) Rescue of the corpus luteum and an increase in luteal superoxide dismutase expression induced by placental luteotropins in the rat: action of testosterone without conversion to estrogen Biology of Reproduction 62 398-403

Thorneycroft IH, Mishell DR, Jr, Stone SC, Kharma KM and Nakamura RM (1971) The relation of serum $17 \alpha$-hydroxyprogesterone and estradiol$17 \beta$ levels during the human menstrual cycle American Journal of Obstetrics and Gynecology 111 947-951

Townson DH and Pate JL (1996) Mechanism of action of TNF- $\alpha$-stimulated prostaglandin production in cultured bovine luteal cells Prostaglandins $52361-373$

*Townson DH, Warren JS, Flory CM, Naftalin DM and Keyes PL (1996) Expression of monocyte chemoattractant protein-1 in the corpus luteum of the rat Biology of Reproduction 54 513-520

Vernon-Roberts B (1969) The effects of steroid hormones on macrophage activity International Review of Cytology 25 131-159

Vickers SL, Cowan RG, Harman RM, Porter DA and Quirk SM (2000) Expression and activity of the Fas antigen in bovine ovarian follicle cells Biology of Reproduction 62 54-61

Voll RE, Herrmann M, Roth EA, Stach C, Kalden JR and Girkontaite I (1997) Immunosuppressive effects of apoptotic cells Nature 390 350-351

Wang F, Riley JGM and Behrman HR (1993) Immunosuppressive levels of glucocorticoid block extrauterine luteolysins in the rat Biology of Reproduction 49 66-73

Weetman AP and Rees AJ (1988) Synergistic effects of recombinant tumor necrosis factor and IFN-gamma on rat thyroid cell growth and la antigen expression Immunology 63 285-290

Wira CR and Rossoll RM (1995) Antigen-presenting cells in the female reproductive tract: influence of the estrous cycle on antigen presentation by uterine epithelial and stromal cells Endocrinology 136 4526-4534

Wira CR, Rossoll RM and Kaushic C (2000) Antigen-presenting cells in the female reproductive tract: influence of estradiol on antigen presentation by vaginal cells Endocrinology $1412877-2885$

Wu XM and Carlson JC (1990) Alterations in phospholipase $A_{2}$ activity during luteal regression in pseudopregnant and pregnant rats Endocrinology 127 2464-2468

Wuttke W, Pitzel L, Knoke I, Theiling K and Jarry H (1997a) Immuneendocrine interactions affecting luteal function in pigs Journal of Reproduction and Fertility Supplement 52 19-29

Wuttke W, Theiling K and Hinney B (1997b) Estrogen, progesterone receptor and TNF gene expression in human and porcine large luteal cells Biology of Reproduction $\mathbf{5 6}$ Supplement $\mathbf{1} 110$

Wuttke W, Spiess S, Knoke I, Pitzel L, Leonhardt S and Jarry H (1998) Synergistic effects of prostaglandin $F_{2 \alpha}$ and tumor necrosis factor- $\alpha$ to induce luteolysis in the pig Biology of Reproduction 58 1310-1315

Zhao Y, Burbach JA, Roby KF, Terranova PF and Brannian JD (1998) Macrophages are the major source of tumor necrosis factor $\alpha$ in the porcine corpus luteum Biology of Reproduction 59 1385-1391

Zolti M, Meirom R, Shemesh M, Wollach D, Mashiach S, Shore L and Rafael ZB (1990) Granulosa cells as a source and target organ for tumor necrosis factor $\alpha$ FEBS Letters $261253-255$ 